\title{
ESTIMATES OF CORRELATION COEFFICIENT, PATH ANALYSIS AND STEPWISE REGRESSION FOR SOME QUANTITATIVE TRAITS IN BREAD WHEAT
}

\author{
E. L. Elmassry(1) and M.H. EL Shal(2) \\ (1) Wheat Research Department, Field Crops Research Institute, A.R.C. \\ (2) National Gene Bank - Agriculture Research Center (ARC). Giza, Egypt
}

Received: Dec. 26,2020

Accepted: Dec. 31,2020

\begin{abstract}
Twenty-five local and exotic wheat genotypes (Triticum aestivum L.) had evaluated to establish genetic variability, correlation coefficient, parameters, the interrelationships, direct and indirect effect and stepwise regression of various wheat components on grain yield. The study was conducted on the Experimental Farm of Gemmeiza Agriculture Research Station, Egypt during two seasons (2018/2019 and 2019/2020). Mean square analysis for the studied characters showed highly significant differences between most of the studied characters except, no. of spikes $/ \mathrm{m}^{2}$ in the second season. According to the results of mean performance, it may be noted that the studied genotypes out yielded grain yield /plot of the overall of the two years. The results of genetic parameters indicated that, both of phenotypic and genotypic coefficients of variation reflected high values, which estimated for three characters; Grain yield /plot followed by grain filling rate and spike weight, respectively. Broad sense heritability cleared that there was graduation for all of studied characters, which values ranged from 50.57 for no. grains/ spike to 93.06 for days to maturity. Three characters; days to heading, days to maturity and plant height gave a small significant values with grain yield character as well as no. spikes $/ \mathrm{m}^{2}$ for phenotypic correlation. Meanwhile, the remain studied characters may showed highly significant values for both of phenotypic and genotypic correlations and could be considered as a good criteria for selection to improve the performance of grain yield. The results for path coefficient illustrate that, the most important sources of variation in grain yield are the direct effect of spike weight followed by 1000 -kernel weight. As for a positive indirect path coefficient; seven positive indirect path coefficients were found as follow: grain filling rate had the highest indirect effect, an appreciable indirect effect via spike weight followed by the relationship between grain filling rate via no. spike $/ \mathrm{m}^{2}$, grain filling rate via no. spikes $/ \mathrm{m}^{2}$, grain filling period via spike weight, spike weight via no. spike/m2, grain filling period via no. spikes $/ \mathrm{m}^{2}$ and grain filling period via no. spike $/ \mathrm{m}^{2}$. On contrary, two negative indirect path coefficients appeared among 1000-kernel weight via spike weight and 1000-kernel weight via no. spike $/ \mathrm{m}^{2}$. Stepwise regression analysis showed that, grain filling period, grain filling rate and plant height as important traits affecting grain yield in wheat
\end{abstract}

Key words: Wheat-correlation-phenotypic and genotypic coefficients-heritability-path coefficient and stepwise regression

\section{INTRODUCTION}

Wheat (Triticum aestivum L.) is an important food crop which used mainly to produce flour used for making bread. Wheat is widely grown in the world and stands first among the cereals in both area and production. Most of the agronomic characters in crop plants are quantitative in nature. Yield is one of such character that results due to the actions and interactions of various component characters (Grafius, 1960). 
Development of new bread wheat cultivars needs efficient tools to monitor trait association in a breeding program. The efficiency of a breeding program depends mainly on, the direction of the correlation between various traits and relative importance of each component involved in contributing to grain yield. It is also widely recognized that genetic architecture of yield can be resolved better by studying its component characters. This enables the plant breeder to select high yielding genotypes with desired combinations of traits. Linear correlation between yield and several of its components can present a confusing picture due to interrelationships between component characters themselves. Simple correlation is partitioned into phenotypic (that can be directly observed), genotypic (inherent association between characters) and environmental (environmental deviation together with non additive genetic variation) components (Singh and Chaudhary, 1985). Saleem et al., (2006) reported that, grain yield per plant was positively and significantly correlated with number of tillers per plant and 1000-grain weight. On the other hand, path coefficient analysis has been found to give more specific information on the direct and indirect influences of each of the component characters upon grain yield. Understanding the interrelationship between component characters helps in determining which character to select when improvement of the related complex character is desired (Solomon and Hanchinal, 2013). Mecha et al., (2017), reported that, grain yield had positive correlation with grain filling period, number of productive tillers per plant, number of kernels per spike and 1000 - kernel weight. In addition, path coefficient analysis showed that, 1000kernel weight and number of kernels per spike showed positive direct effect. Phenotypic and genotypic correlation values indicated that the degree of which various morphological characters are associated with economic productivity. Singh and Diwivedi (2002) studied phenotypic and genotypic correlation in wheat, they showed that, grain yield per plant had a positive significant association with the number of effective tillers per plant. Stepwise regression is a method that is use to estimate the value of a quantitative variable regarding its relation with one or some other quantitative variables. This relation showed that it is possible to predict other changes using one variable. Many investigators used this technique on wheat such as Fouad, (2018). Therefore, the present study was undertaken to assess the diversity between genotypes by estimating genotypic and phenotypic correlations between yield and yield attributing traits as well as assessing the usefulness of applying to the direct and indirect effects of these component traits on grain yield.

\section{MATERIALS AND METHODS}

The field experiments were carried out at Gemmeiza Agriculture Research Station through two successive seasons on twenty-five wheat genotypes (g) (Triticum aestivum L.). Out of these twenty-five genotypes had, nine Egyptian commercial varieties (Gemmeiza 9, Gemmeiza12, Giza168, Sakha 94, Sids1, Sids12, Sids14, Misr 2 and Misr 3) as well as five promising lines selected from wheat research program at Gemmeiza Agricultural Research Station and eleven exotic materials from CIMMYT and ICARDA (Table 1). The experiment was conducted in two successive seasons (2018/2019 and 2019/2020) in a randomize complete block design (RCBD) with three replicates. Each genotype (g) was grown in six rows, each row 4 meters long and $20 \mathrm{~cm}$ apart. Plants within rows were 20 cm distant. All recommended agricultural practices were applied for planting to harvest in two seasons. 
Table (1). Name, pedigree and source of the studied bread wheat genotypes.

\begin{tabular}{|c|c|c|c|}
\hline No. & Name & Pedigree and selection history & Source \\
\hline 1 & Gemmeiza9 & $\begin{array}{l}\text { ALD "S" /HUAC I/ CMH } 74 \text { A. 630/SX } \\
\text { CGM } 4583 \text { - } 5 \text { GM - 1GM - OGM }\end{array}$ & Egypt \\
\hline 2 & Gemmeiza 12 & $\begin{array}{l}\text { OTUS/3/SARA/THB//VEE } \\
\text { CMSS97YOO227 S-5Y-010M-010Y- 010M-2Y - 1M-0Y- OGM }\end{array}$ & Egypt \\
\hline 3 & Giza 168 & $\begin{array}{l}\text { MRLI BUCII SERI } \\
\text { CM 93046-8 M-OY-OM-2Y-OB-OGZ }\end{array}$ & Egypt \\
\hline 4 & Sakha 94 & $\begin{array}{l}\text { OPATA I RAYON II KAUZ } \\
\text { CMBW90Y3180-0TOPM-3Y-010M-010M-010Y-10M-015Y-0Y-0AP-S. }\end{array}$ & Egypt \\
\hline 5 & Sids1 & $\begin{array}{l}\text { HD2173/PAVON"S"I/1158.57/MAYA } 74 \text { "S" } \\
\text { SD46-4SD-2SD-1SD-0SD }\end{array}$ & Egypt \\
\hline 6 & Sids12 & $\begin{array}{l}\text { BUS//7C//ALD/5/MAYA74/ON//1160.147/3/BB/GLL/4/CHAT"S"/6/MAYA/V } \\
\text { UL//CMH74A.630/4*SX. } \\
\text { SD720096-4SD-1SD-1SD-0SD }\end{array}$ & Egypt \\
\hline 7 & Sids14 & $\begin{array}{l}\text { SW8488*2/ KUKUNA } \\
\text { CGSS01Y00081T-099M-099Y-099M-099B-9Y-0B-0SD }\end{array}$ & Egypt \\
\hline 8 & Misr2 & $\begin{array}{l}\text { SKAUZ/BAV92 } \\
\text { CMSS96M03611S-1M-0105Y-010M-010SY-8M-OY-OS }\end{array}$ & Egypt \\
\hline 9 & Misr3 & $\begin{array}{l}\text { ATTILA*2/PBW65*2/KACHU } \\
\text { CMSS06Y00582T-099TOPM-099Y-099ZTM-099Y-099M-10WGY-0B-0EGY }\end{array}$ & Egypt \\
\hline 10 & Line 1 & $\begin{array}{l}\text { KVZ/CMH82493//COMPACT*4/3/GEM\#7/7/CMH83.2517/ELVIRA/6/CMH79 } \\
\text { A955/4/AGA/3/4*SN64/CNO67/IINIA66/5/NAC } \\
\text { CGM9439-3GM-1GM-3GM-4GM-2GM-2GM-4GM }\end{array}$ & Egypt \\
\hline 11 & Line 2 & $\begin{array}{l}\text { HEILO/ELVIRA/ I WBLL1*2/KIRITATI } \\
\text { CGM10-103647-2GM-2GM-2GM-2GM-0GM }\end{array}$ & Egypt \\
\hline 12 & Line 3 & $\begin{array}{l}\text { TV870344/GUI/TEMPORALERA M 87/AGR/3/2*WBLL1/4/ OASIS I } \\
\text { SKAUZ I/4*BCN/3/2*PASTOR } \\
\text { CGM10-103661-4GM-2GM-2GM-1GM-0GM }\end{array}$ & Egypt \\
\hline 13 & Line 4 & $\begin{array}{l}\text { TIMBA/ELVIRA/I WBLL1*2/KKTS } \\
\text { CGM10-103645-3GM-1GM-1GM-1GM-0GM }\end{array}$ & Egypt \\
\hline 14 & Line 5 & $\begin{array}{l}\text { SIDS1/ ATTILA // GOUMRIA-17 } \\
\text { S. 16498-042S-013S-21S -0S }\end{array}$ & Egypt \\
\hline 15 & Line 6 & $\begin{array}{l}\text { PBW343*2/KUKUNA//SRTU/3/PBW343*2/KHVAKI/4/VORB/FISCAL//AKU } \\
\text { RI \#1/5/ PBW343*2/KUKUNA I/SRTU/3/ PBW343 *2/KHVAKI } \\
\text { CMSS11Y00928T-099TOPM-099Y-099M-099NJ-099NJ-12WGY-0B }\end{array}$ & CIMMYT \\
\hline 16 & Line 7 & $\begin{array}{l}\text { UP2338*2/SHAMA/3/MILAN/KAUZI/CHIL/CHUM18/4/UP2338*2/SHAMA*2/ } \\
\text { 5/PBW343*2/KUKUNA*2/IFRTL/PIFED } \\
\text { CMSS11Y00993T-099TOPM-099Y-099M-099NJ-099NJ-6WGY-0B }\end{array}$ & CIMMYT \\
\hline 17 & Line 8 & $\begin{array}{l}\text { D67.2/PARANA66.270//AE.SQUARROSA(465)/7/CHWL86/6/FILIN/IRENA } \\
\text { I5/ CNDO/R143//ENTE/MEXI_2/3/AEGILOPS SQUARROSA (TAUS) /4 } \\
\text { IWEAVER } \\
\text { PTSS11Y00160S-0SHB-099Y-099B-099Y-11Y-020Y-0B }\end{array}$ & CIMMYT \\
\hline 18 & Line 9 & $\begin{array}{l}\text { CETA/AE.SQUARROSA(435)/7/2*CHWL86/6/FILIN/IRENA/5/CNDO/R143/I } \\
\text { ENTE/MEXI_2/3/AEGILOPS SQUARROSA (TAUS)/ 4/ WEAVER } \\
\text { PT12SHB00008T-099Y-099B-099Y-15B-020Y-0B-0B }\end{array}$ & CIMMYT \\
\hline 19 & Line 10 & $\begin{array}{l}\text { CETAIAE.SQUARROSA (435)//2*BECARD } \\
\text { PT12SHB00021T-099Y-099B-099Y-17B-020Y-0B-0B }\end{array}$ & CIMMYT \\
\hline 20 & Line 11 & $\begin{array}{l}\text { SERI.1B*2/3/KAUZ*2/BOWI/KAUZ/4/PFAU/MILAN } \\
\text { AISBW05-0327-6AP-0AP-0AP-3AP-0AP }\end{array}$ & ICARDA \\
\hline 21 & Line 12 & $\begin{array}{l}\text { SERI.1B//KAUZ/HEVO/3/AMAD/4/PFAU/MILAN } \\
\text { ICW06-00151-8AP-0AP -1 SD }\end{array}$ & ICARDA \\
\hline 22 & Line 13 & $\begin{array}{l}\text { GIZA 164/SAKHA34/ISIEF-7 } \\
\text { ACS-W-10121(2005)-0IZ-0IZ-5IZ-0IZ }\end{array}$ & ACSAD \\
\hline 23 & Line 14 & $\begin{array}{l}\text { CHAM-6/GHURAB'S'/IMELLAL-1 /3/ OTEIK } \\
\text { ACS-W-10877(2010)-14IZ-3IZ-2IZ-0IZ }\end{array}$ & ACSAD \\
\hline 24 & Line 15 & $\begin{array}{l}\text { TRCH/5/REH/HAREI/2*BCN/3/CROC_1/AE.SQUARROSA(213)//PGO/4/HU } \\
\text { ITES/6/SAUAL/3/C80.1/3*BATAVIA//2*WBLL1/4/SITE/MOI/PASTOR/3/TIL } \\
\text { HI } \\
\text { CMSS11Y00063S-099Y-099M-0SY-8M-0WGY }\end{array}$ & CIMMYT \\
\hline 25 & Line 16 & $\begin{array}{l}\text { UP2338*2/SHAMA/3/MILAN/KAUZ//CHIL/CHUM18/4/UP2338*2/SHAMA*2I } \\
\text { 5/PBW343*2/KUKUNA*2//FRTL/PIFED } \\
\text { CMSS11Y00993T-099TOPM-099Y-099M-099NJ-099NJ-2WGY-0B }\end{array}$ & CIMMYT \\
\hline
\end{tabular}


Data were collected from each plot on 10 quantitative characters, namely; days to heading $(\mathrm{DH})$, days to maturity (DM), grain-filling period (GFP), grain-filling rate (GFR), plant height $(\mathrm{PH})$, number of spikes $/ \mathrm{m}^{2}$ (no. $\mathrm{S} / \mathrm{m}^{2}$ ), number of grains Ispike (no. G/S), spike weight (SW), 1000Kernel weight (1000-KW) and grain yield Iplot (GY/P).

\section{Statistical analysis:}

The statistical analysis was carried out by Paleontological Statistics (PAST) Version 3.08 (Dryden and Mardia, 1998) to determine mean square, correlation coefficient and cluster analysis. The phenotypic and genotypic variances were calculated from partitioning mean squares expectation; where, $g$ and $r$ are the number of genotypes and replications, respectively.

Phenotypic and genotypic correlation coefficients calculated as outlined by Kwon and Torrie (1964) from the corresponding variance and covariance components as follows:

$$
R_{G}=\operatorname{cov}_{G}\left(x_{1}, x_{2}\right) / \sqrt{ } V_{G}\left(x_{1}\right) \cdot v_{G}\left(x_{2}\right)
$$

Where, $\operatorname{cov}_{\mathrm{G}}\left(\mathrm{x}_{1}, \mathrm{x}_{2}\right)=$ Genetic covariance among $x_{1}$ and $x_{2} ; V_{G}\left(x_{1}\right)$ and $V_{G}\left(x_{2}\right)=$ Genetic variance for character $x_{1}$ and $x_{2}, \quad$ respectively. Genotypic correlation tested for its statistical significance using the method for both of Reeve, (1955) and Robertson, (1959). The genotypic correlation was considered significant if its absolute value exceeded the twice of its respective standard value.

$R_{\mathrm{P}}=\operatorname{COV}_{\mathrm{P}}\left(\mathrm{x}_{1}, \mathrm{x}_{2}\right) / \sqrt{ } \mathrm{V}_{\mathrm{P}}\left(\mathrm{x}_{1}\right) \cdot \mathrm{V}_{\mathrm{P}}\left(\mathrm{x}_{2}\right)$

Where, cov p $\left(x_{1}, x_{2}\right)=$ Phenotypic covariance among character $x_{1}$ and $x_{2}$; $V p(x 1)$ and $V p\left(x_{2}\right)=$ Phenotypic variance for character $x_{1}$ and $x_{2}$, respectively. Statistical significance of phenotypic correlation coefficients was determined by using " $t$ " test as described by Steel et al., (1997).
Broad sense heritability $\left(\mathrm{H}^{2} \quad\right.$ в) was estimated from the formula of (Roy, 2000) as follows; $\delta^{2} \mathrm{~g}=\mathrm{MS}_{\mathrm{g}}-\mathrm{MS}_{\mathrm{e}} / \mathrm{r} \delta^{2} \mathrm{ph}=\delta^{2} \mathrm{~g}+$ $\delta^{2} \mathrm{e} / \mathrm{r} \mathrm{H}^{2}=\delta^{2} \mathrm{~g} / \delta^{2} \mathrm{ph}$ Where; $\delta^{2} \mathrm{~g}=$ genotypic variance $\delta^{2} \mathrm{ph}=$ phenotypic variance

Genetic advance (GA) calculated according to the method suggested by Allard (1960) and Singh and Chaudhury (1985) using Equation:

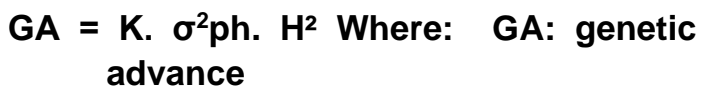

The mean values used for genetic analyses to determine the phenotypic coefficient of variation (PCV) and genotypic coefficient of variation (GCV), according to Singh and Chaudhury (1985) using Equations: $\mathrm{PCV}=\left(\sqrt{ } \delta^{2} \mathrm{~g} / \overline{\mathrm{x}}\right) \times 100$ Genotypic coefficient of variation (GCV) = $\left(\sqrt{ } \delta^{2} \mathrm{ph} / \overline{\mathbf{x}}\right) \times 100$

Where: $\overline{\mathbf{x}}=$ sample mean

Stepwise regression calculated according to Draper and Smith (1981) and used Minitab (2020) 19 software to detect the most important traits (independent variables) significantly contributed to grain yield (dependent variable) characters.

\section{RESULTS AND DISCUSSION}

\section{Genetic variability:}

The mean squares of all studied characters were recorded on all genotypes for yield and its components are presented in (Table 2). The results of the two successive seasons of variance for genotypes showed a highly significant difference between genotypes except for no. spikes $/ \mathrm{m}^{2}$ in the second season. Interaction mean squares between genotypes and year were significant for all studied traits except for plant height. These results indicated that there was variability among the studied 


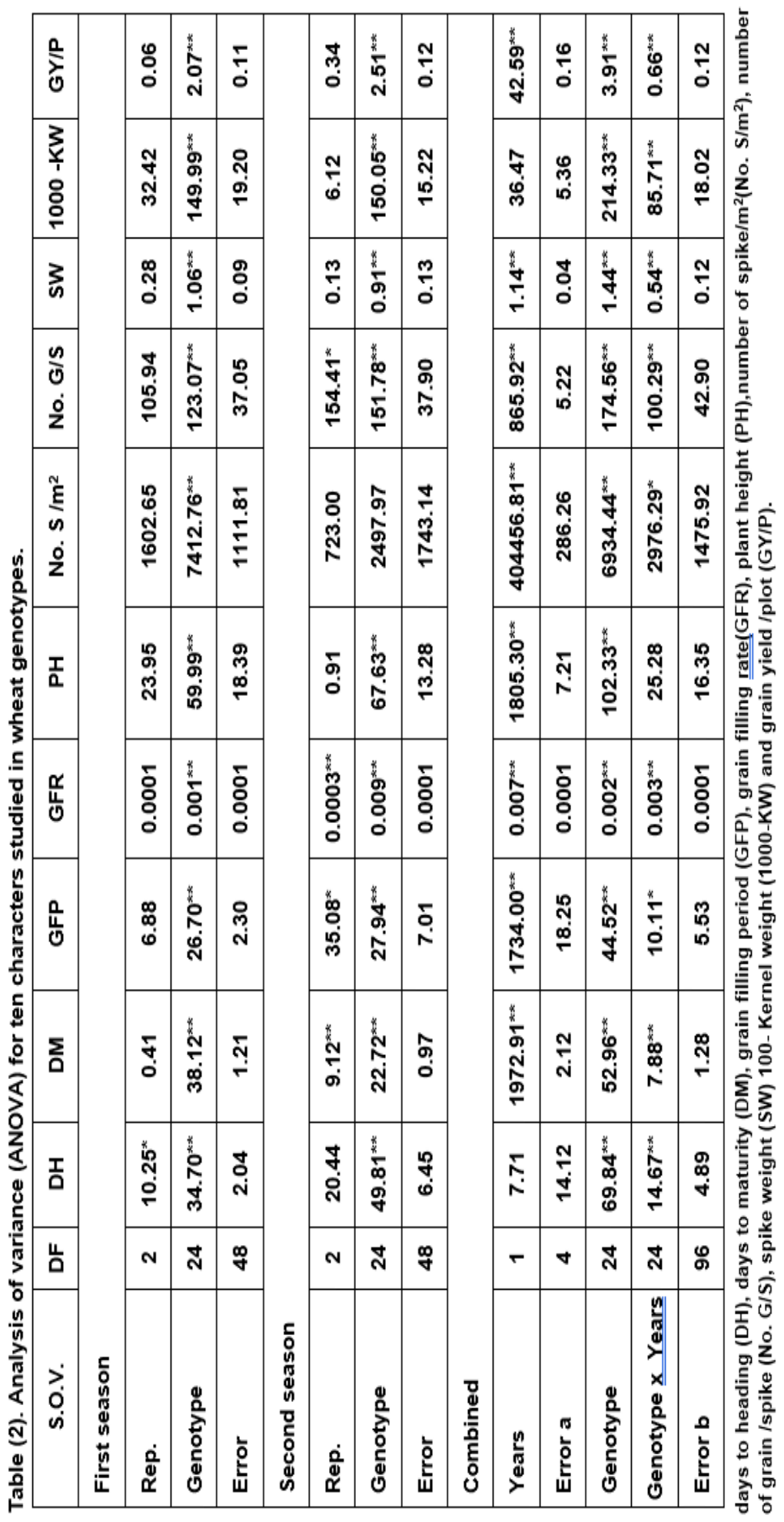


genotypes and they would respond positively to selection. Thus, it is indicates ample scope for selection for different quantitative characters for wheat improvement. These results are in harmony with those previously obtained by Fikre et al., (2015), Dargicho et al., (2015), Arya et al., (2017) and Baye et al., (2020).

\section{Mean performance:}

The mean performance of the twentyfive genotypes of wheat as well as their combined data for all the studied agronomic traits are presented in Table (3). Results showed that genotypes had significant effects for all the studied agronomic characters. Based on a twoyear data and their combined analysis, all examined characteristics showed wide range of variation in all studied characters. According to a considerable range of variations may be provide a good opportunity for yield improvement. For days to heading, the genotype (g14) was the earliest, followed by the genotype (g11) under combined analysis. The data demonstrated clearly that there were marked differences among genotypes in days to heading.

Regarding days to maturity, two commercial varieties (Sids 12 and Gemmeiza12) in addition the genotype (g11) showed the lowest mean values in the two years and combined analysis. The shortest mean value for grain filling period were for the two commercial varieties Gemmeiza12 and Gemmeiza 9 in the two-years and overall of the two years. The data of grain filling rate illustrate that the two commercial varieties Sakha 94 and Misr 3 in addition to the genotype (g 25) had the highest mean values for two years data and overall two years. Concerning to plant height, the two commercial varieties; Gemmeiza12 and Sids 12 possessed the shortest plants while, g 23 gave the tallest plants for two years data and overall two years. For a number of spikes $/ \mathrm{m}^{2}$ both of $\mathrm{g} 20$ revealed the highest values for two-year data and overall two years. Regarding number of grains /spike g 3 showed the highest mean values mean at first year and g19 in second years while, Gemmeiza 12 recorded the lowest values for overall two years. On the other hand, data from spike weight trait showed that three genotypes; g18, g 25 and g 16 recorded the highest weight values in the first year, The data from $1000-K e r n e l$ weight trait clearly that g18 showed the highest values in the first year and $g 9$ in the second year meanwhile, the g12 showed the lowest values for overall two years. The data of grain yield I plot at first year recorded that Misr3 and $g 25$ recorded the highest mean values. On the contrary, the commercial variety Misr 2 recorded the lowest weight per plot of two-year data and overall two years. The current results are similar to the findings obtained by Baloch et al., (2013) and Abd El-Kreem and Fateh (2016).

According to the previous results of mean performance, it could be noted that the genotype (g11) showed the lowest values for, days to heading and maturity. Earliness if it is found in wheat is favorable for escaping from disease as well as high temperature in maturity and stress conditions which have the same effect also. Genotype g 25 recorded the highest grain yield /plot, and could be used in breeding programs for improving the performance of yield and yield components in wheat.

\section{Estimates of GCV, PCV, $\mathrm{H}^{2}$ and GA}

The estimates of phenotypic variances ( $\left.\sigma^{2} \mathrm{ph}\right)$, genotypic variances $\left(\sigma^{2} \mathrm{~g}\right)$, phenotypic coefficients of variation (PCV), genotypic coefficients of variation (GCV), broad sense heritability $\left(\mathrm{H}^{2}\right)$ and genetic advance (GA) are showed in Table 4. 


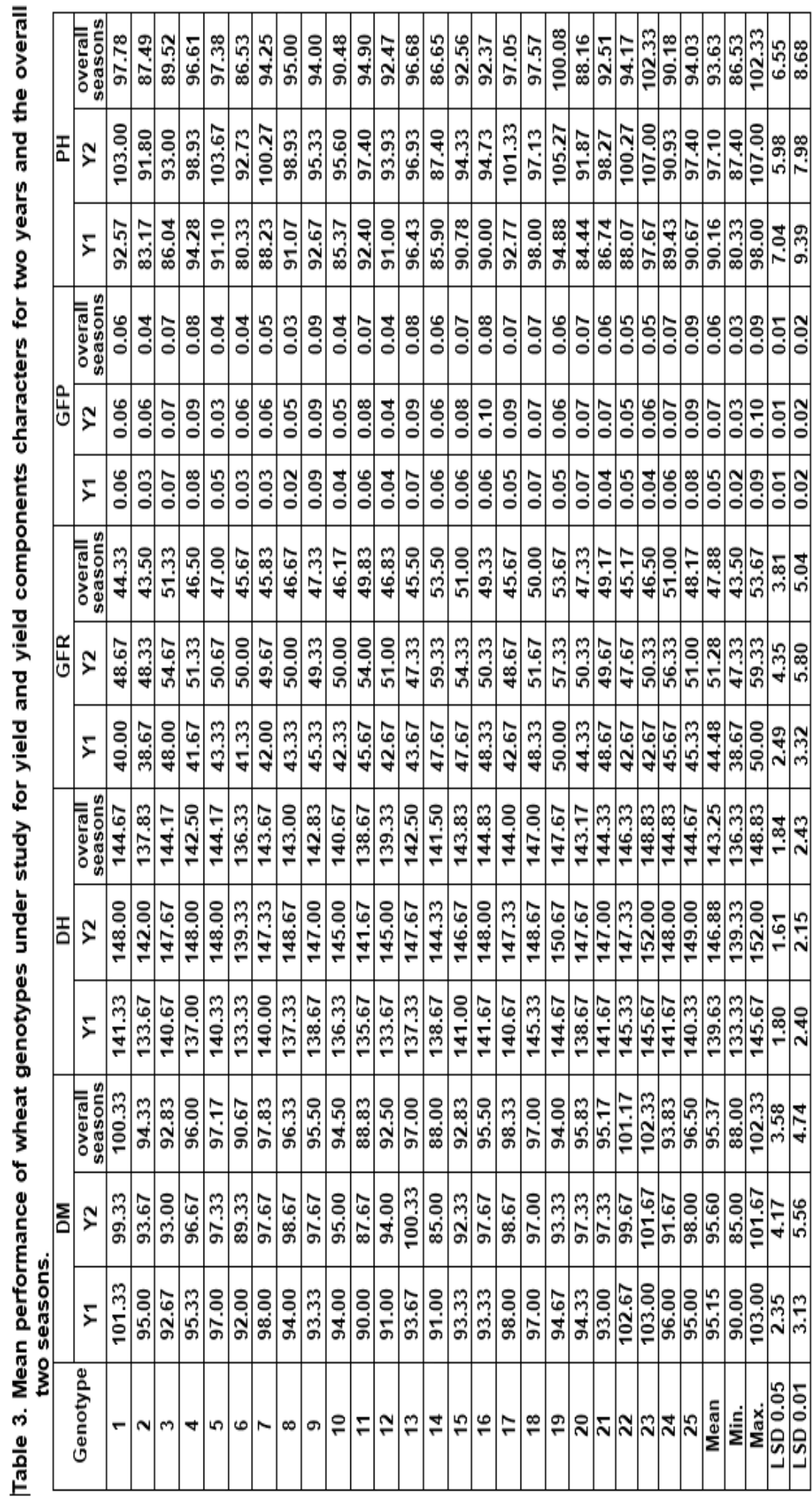




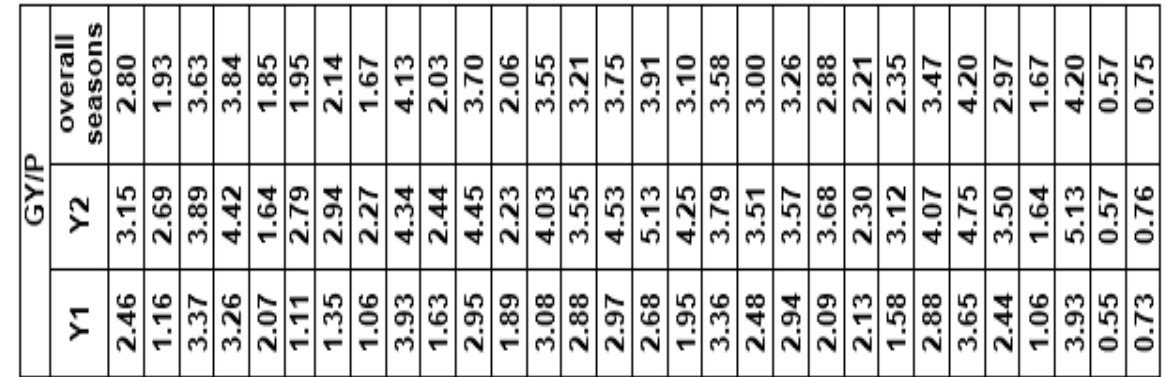

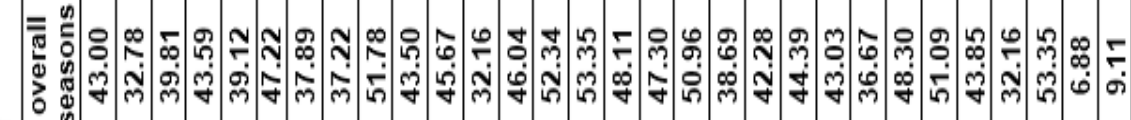
3

N

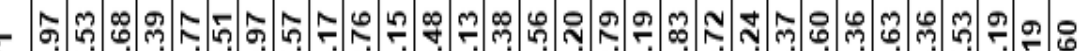

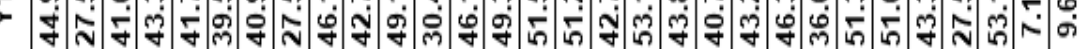

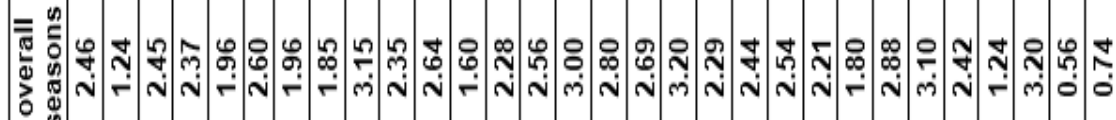

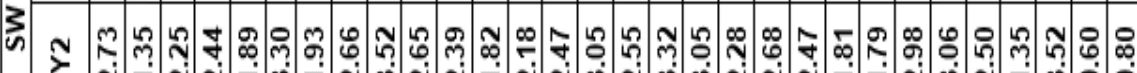

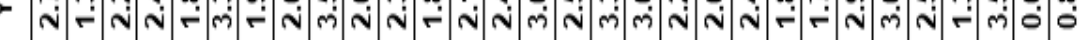

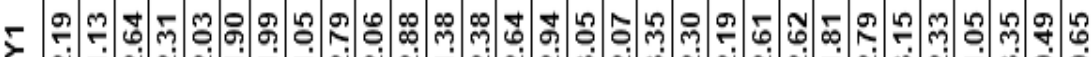

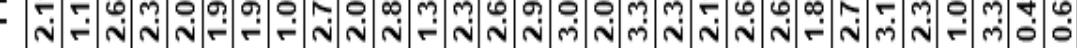

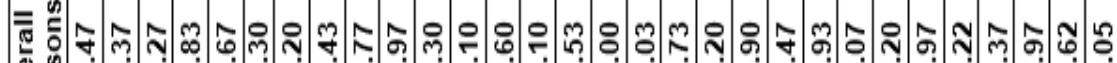

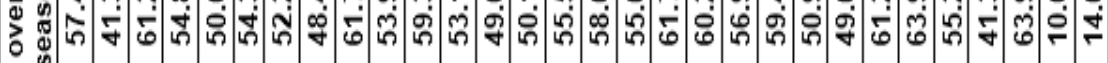

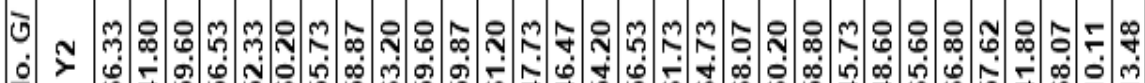
z

b 守

₹

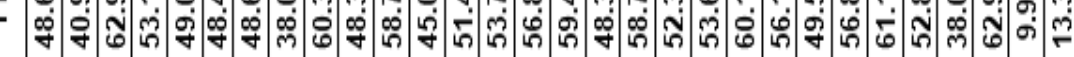

సิ ○.

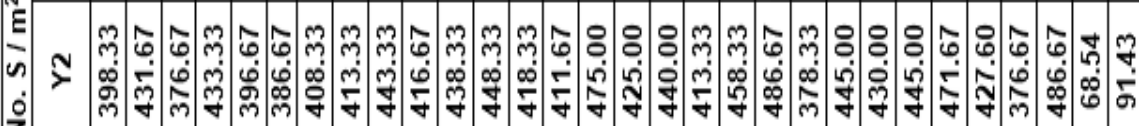
$\dot{0}$

ஸิ

₹

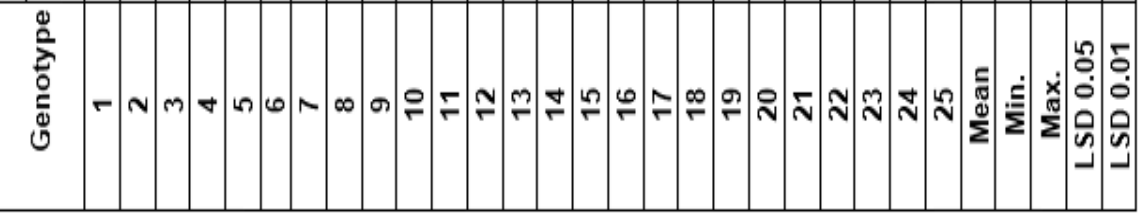


Estimates of correlation coefficient, path analysis and stepwise regression ........

Table (4). Estimation of genetic variability parameters for yield and yield components characters of wheat genotypes

\begin{tabular}{|l|c|c|c|c|c|c|c|c|c|c|}
\hline & DH & DM & GFP & GFR & PH & $\begin{array}{c}\text { No. } \\
\text { S/m }\end{array}$ & $\begin{array}{c}\text { No. } \\
\text { G/S }\end{array}$ & SW & $\begin{array}{c}1000- \\
\text { KW }\end{array}$ & GY IP \\
\hline$\delta^{2} \mathrm{e}$ & 4.89 & 1.28 & 5.53 & 0.0001 & 16.35 & 1475.92 & 42.90 & 0.12 & 18.02 & 0.12 \\
\hline$\delta^{2} \mathrm{~g}$ & 21.65 & 17.23 & 13.00 & 0.0004 & 28.66 & 1819.50 & 43.89 & 0.44 & 65.44 & 1.26 \\
\hline$\delta^{2} \mathrm{ph}$ & 26.54 & 18.51 & 18.53 & 0.0005 & 45.01 & 3295.43 & 86.79 & 0.56 & 83.45 & 1.39 \\
\hline PCV & 5.40 & 3.00 & 8.99 & 38.18 & 7.17 & 15.28 & 16.87 & 30.96 & 20.83 & 39.68 \\
\hline GCV & 4.88 & 2.90 & 7.53 & 35.80 & 5.72 & 11.35 & 12.00 & 27.47 & 18.45 & 37.87 \\
\hline$H^{2}$ & 81.58 & 93.06 & 70.16 & 87.95 & 63.67 & 55.21 & 50.57 & 78.74 & 78.41 & 91.08 \\
\hline GA & 8.66 & 8.25 & 6.22 & 0.04 & 8.80 & 65.29 & 9.70 & 1.21 & 14.76 & 2.21 \\
\hline
\end{tabular}

$\delta^{2} \mathbf{e}=$ Environment variance, $\delta^{2} \mathbf{g}=$ Genotypic variance, $\delta^{2} \mathrm{ph}=$ Phenotypic variance, $\mathrm{PCV}=$ Phenotypic coefficient of variance, $\mathrm{GCV}=$ Genotypic coefficient of variance, $\mathrm{H}^{2}=\mathrm{Broad}$ sense heritability and GA = Genetic advance.

The genotypic coefficient of variation for the entire examined attributes was less than the phenotypic coefficient of variation. The results indicated that the extent of phenotypic and genotypic variances diverse from one character to another. Both of (PCV) and (GCV) reflected high values which were estimated for three characters; grain yield /plot with values of $\mathbf{3 9 . 6 8}$ and $\mathbf{3 7 . 8 7}$ followed by grain filling rate with values of 38.18 and 35.80 and spike weight with values of 30.96 and 27.47 , respectively. Whereas, the three characters; 1000kernel weight, no. grains/ spike and no. spikes $/ \mathrm{m}^{2}$ showed a relatively moderate level of (PCV) and (GCV) with values of 20.83 and 18.45, 16.87 and 12.00 and 15.28 and 11.35, respectively. Meanwhile, the four characters; grain filling period, plant height, days to heading and days to maturity recorded the lowest (PCV)and (GCV) with values of 8.99 and 7.53, 7.17 and 5.72, 5.40 and 4.88 and 3.00 and 2.90, respectively. In general, The PCV values were higher than GCV values for all the characters studied which reflect the influence of environment on the expression of these traits. Earlier wheat researchers reported similar results (Ali et al., 2008, Demelash et al., 2013, Nukasani et al., 2013 and Hussain et al., 2014).

The results of broad sense heritability $\left(\mathrm{H}^{2}\right)$ estimates clear that, there was graduation for all of studied characters with values ranged from 50.57 to 93.06. The highest value observed was 93.06 for days to maturity followed by grain yield Iplot with value 91.08, grain filling rate with value 87.95 and days to heading with value 81.58. There were moderately high broad sense heritability values for spike weight with the value 78.74 followed by 1000-kernel weight with value 78.41 and grain filling period with value 70.16. On the contrary, the lowest values had recorded for three characters; plant height, no. spikes $/ \mathrm{m}^{2}$ and no. grains/ spike with values of $63.67,55.21$ and 50.57 , respectively. The results showed that, high broad sense heritability indicating that the effect of environment was lower than genetic effect in the inheritance of the studied traits. In addition, high estimates of heritability may be successful for improving wheat. Similar findings data were reported by Hussain et al., (2014) who found that high heritability estimates for grain yield per 
plot (93.34) and number of spike $/ \mathrm{m}^{2}$ (84.80). Ali et al., (2008) reported moderate heritability for number of productive tillers per plant. Also, High heritability estimates were recorded for plant height, number of spikelets per spike, spike length, number of grains per spike, 1000 grain weight and yield per plant.

Heritability and genetic advance are important selection parameters. Heritability estimates along with genetic advance are normally more helpful in predicting the gain under selection than heritability estimates alone (Johnson et al., 1955).

In the present investigation, high heritability value with high genetic advance was obtained for No. of spikes $/ \mathrm{m}^{2}$ and 1000-kernel weight indicates that, most likely heritability in narrow sense is due to additive gene effects and the selection may be effective in early generations for these traits. This results revealed that, high estimates of $h^{2}$ and genetic advance for these traits might be helpful for the plant breeders to select the best combination to reach the desirable level of yield potential in wheat.

High heritability for grain filling rate, spike weight and grain yield I plant coupled with low genetic advance indicates non-additive gene effects. Therefore, it is expected limited scope of improvement in this trait. The current conclusions are supported by Baloch et al., (2013) and Abd El-Kreem and Fateh (2016) who confirmed that plant breeders may be safely make their selection when they took in consideration the high values of heritability and genetic advance.

\section{Correlation coefficient analysis:}

Grain yield is a quantitative character and influenced by environment. It is multiplicative end product of numerous genetically controlled traits which singly or jointly influence it. Therefore, good knowledge of association of these characters is vital importance for selection of high yielding genotypes. The genotypic and phenotypic correlations are presented in Table (5). Days to heading recorded negative association with grain yield per plot at both phenotypic and genotypic levels ( $r p=$ 0.16, $\mathrm{rg}=-$ 0.19). However, the associations were insignificant, there was two phenotypic correlation each with days to maturity with value of $\mathrm{rp}=0.59$ and plant height with value of $r p=0.49$ in addition, a negative phenotypic correlation with grain filling period with value of $r p=-0.59$. Meanwhile three genotypic correlation coefficient; two positive correlation with days to maturity with value of $\mathrm{rg}=0.69$ and plant height with value of $\mathrm{rg}=0.72$ and there was negative values each with grain filling period with value of $r g=-0.52$. As for days to maturity showed positive association with grain yield per plot at both phenotypic and genotypic levels of $\mathrm{rp}=$ $0.21, \mathrm{rg}=0.24$, however, the correlations were insignificant too. There was high positive phenotypic and genotypic correlations each with plant height with values $r p=0.57$ and $r g=0.69$, respectively. Negative correlation coefficients indicated that, their inverse relationship with each other. Ismail (2001) and Khokhar et al., (2010) found similar results in their studies. Regarding to grain filling period clear that highly positive phenotypic with each of grain yield/plot with value of $r p=0.40$ as well as the genotypic correlation coefficient with value of $\mathrm{rg}=0.53$ according to phenotypic correlations two positive significant relationship for trait with each no. grains/ spike and spike weight with value rp $=0.40$ and 0.40 . In addition, three positive significant genotypic correlation coefficients each with no. grains/ spike, spike weight and 1000- kernel weight with 
values $(\mathrm{rg}=0.60,0.49$ and 0.43$)$, respectively. The value of the correlation coefficient between grain filling rate with grain yield/plot showed positive phenotypic with value $r p=0.97$ as well as the genotypic correlation coefficient with value $\mathrm{rg}=0.98$.

From phenotypic and genotypic correlations three positive significant relationship were found with each of them i.e., grain filling rate with; no. grains/ spike, spike weight and 1000kernel weight with, values of $r p=0.50$, 0.63 and 0.57 and values of $\mathrm{rg}=0.60,0.49$ and 0.43 , respectively. The data for plant height showed positive association with grain yield per plot at both phenotypic and genotypic levels of $\mathrm{rp}=0.06, \mathrm{rg}=$ 0.04 . However, the associations were insignificant. Phenotypic and genotypic correlations coefficient between no. spikes $/ \mathrm{m}^{2}$ each with grain yield/plot which showed a highly positive significant for genotypic correlation with the value of $\mathrm{rg}=0.53$ meanwhile, gave a small significant positive value for phenotypic correlation coefficient meanwhile, two positive genotypic correlation each with no. grains/ spike and spike weight with values of $\mathrm{rg}=0.51$ and0.47, respectively. As for no. grains Ispike showed positive association with grain yield per plot for both phenotypic and genotypic levels of $\mathrm{rp}=0.55, \mathrm{rg}=$ 0.79 . The value of correlation coefficient between previous character for phenotypic and genotypic correlations showed one positive significant phenotypic correlation with value of $r p$ $=0.74$ and two positive significant relationship for genotypic correlation each of spike weight and 1000- kernel weight with value $r p=0.85$ and 0.65 , respectively. Regarding to spike weight character revealed that a high positive phenotypic and genotypic correlations with grain yield /plot with values of $\mathrm{rp}$ $=0.68$ and $\mathrm{rg}=0.82$. Similar results for spike weight character showed highly significant positive phenotypic and genotypic correlation with 1000- kernel weight with values of $\mathrm{rp}=0.86$ and $\mathrm{rg}=0.95$, respectively. One significant and highly positive correlation coefficient that detected between the pair characters; 1000- kernel weight each with, a grain yield/plot with value $\mathrm{rp}=0.61$ and $\mathrm{rg}=0.74$, respectively.

Table (5). Upper diagonal estimates of phenotypic (rp) and lower diagonal genotypic correlation $(\mathrm{rg})$ coefficients between grains yield $I$ plot and its nine contributing characters in bread wheat.

\begin{tabular}{|c|c|c|c|c|c|c|c|c|c|c|}
\hline$(\mathrm{rp})$ & DH & DM & GFP & GFR & PH & $\begin{array}{l}\text { No. } \\
\text { S/m² }\end{array}$ & $\begin{array}{l}\text { No. } \\
\text { G/S }\end{array}$ & sW & $\begin{array}{c}1000- \\
\mathrm{Kw}\end{array}$ & GY IP \\
\hline DH & & ** & $-0.59^{* *}$ & -0.02 & $0.49 *$ & 0.06 & -0.11 & -0.17 & -0.21 & -0.16 \\
\hline DM & $0.67^{\star *}$ & & 0.28 & 0.17 & $0.57^{* *}$ & 0.13 & 0.26 & 0.19 & 0.07 & 0.21 \\
\hline GFP & $-0.52^{\star *}$ & 0.28 & & 0.20 & -0.01 & 0.06 & $0.40^{*}$ & $0.40^{*}$ & 0.32 & $0.40^{*}$ \\
\hline GFR & -0.09 & 0.22 & 0.37 & & 0.08 & 0.38 & $0.50^{* *}$ & $0.63^{\star *}$ & $0.57^{\star *}$ & $0.97^{\star \star}$ \\
\hline PH & $0.72^{\star *}$ & $0.69 * *$ & -0.14 & 0.09 & & 0.04 & 0.03 & -0.04 & -0.13 & 0.06 \\
\hline No. $\mathrm{S} / \mathrm{m}^{2}$ & 0.01 & 0.21 & 0.22 & $0.537^{*}$ & 0.01 & & 0.23 & 0.24 & 0.22 & 0.36 \\
\hline No. G/S & -0.16 & 0.34 & $0.60^{* *}$ & $0.74^{* *}$ & 0.12 & $0.51^{* *}$ & & $0.74^{\star *}$ & 0.36 & $0.55^{\text {** }}$ \\
\hline SW & -0.16 & 0.24 & $0.49^{*}$ & $0.79 * *$ & -0.02 & $0.47^{*}$ & $0.85^{* *}$ & & $0.86^{* *}$ & $0.68^{\star \star}$ \\
\hline $1000-K w$ & -0.24 & 0.10 & $0.43^{*}$ & $0.72^{\star *}$ & -0.14 & 0.34 & $0.65^{\star *}$ & $0.95^{\star *}$ & & $0.61^{\text {** }}$ \\
\hline GY IP & -0.19 & 0.24 & $0.53^{* *}$ & $0.98^{* *}$ & 0.04 & $0.53^{\star *}$ & $0.79 * *$ & $0.82^{\star *}$ & $0.74^{\star *}$ & \\
\hline
\end{tabular}


The results confirmed that three character; days to heading, days to maturity and plant height gave a small values to be significant with grain yield character as well as no. spikes $/ \mathrm{m}^{2}$ for phenotypic correlation that reverse relationship between earliness traits and grain yield is eligible especially if stresses such as heat and drought is expected and that means if long duration of the growing period would mean that there could be more accumulation of dry matter during growing period. Similar results from Mohammadi et al., (2012) and Zafarnaderi et al., (2013). They found a negative relationship between days to heading and grain yield per plant in their studies. Meanwhile, remain studied characters showed high significant for both of phenotypic and genotypic correlation and may be considered as good criteria for selection to improve the performance of yield and grain yield/ plot characters. The success of any plant breeding program depends on the extent of genetic variability in the base population. In addition to genetic variation, correlation of yield and yield components will serve to make an effective selection.

\section{Path coefficient:}

Path coefficient analysis helps to estimate the influence of each variable upon the resultant variable directly as well as indirectly by partitioning the genetic correlation coefficients. It provides an effective way of finding out indirect and direct sources of correlation. The coefficients of determination were calculated for the direct and indirect effects of the ten yield studied factors and transformed into percentage in order to evaluate these factors for their importance as sources of variation in grain yield Table (6).

The obtained results illustrate that the most important sources of variation in grain yield are the direct effect of spike weight with value 0.1393 followed by 1000-kernel weight with value direct path coefficient of 0.0202 .

Table (6). Estimates of genotypic path coefficient (direct effect and indirect effect) of different nine characters on grain yield of bread wheat.

\begin{tabular}{|c|c|c|c|c|c|c|c|c|c|c|}
\hline \multirow[b]{2}{*}{ Character } & \multirow{2}{*}{$\begin{array}{l}\text { Direct } \\
\text { effect }\end{array}$} & \multicolumn{9}{|c|}{ Indirect effect } \\
\hline & & DH & DM & GFP & GFR & PH & $\begin{array}{l}\text { No. } \\
\mathrm{S} / \mathrm{m}^{2}\end{array}$ & $\begin{array}{l}\text { No. } \\
\text { G/S }\end{array}$ & sW & $\begin{array}{c}1000- \\
\mathrm{Kw}\end{array}$ \\
\hline DH & 0.0002 & & -0.0003 & 0.0013 & 0.0008 & 0.0001 & 0.0001 & -0.0002 & 0.0005 & $\mid-0.0004$ \\
\hline DM & 0.0013 & 0.0003 & & 0.0018 & 0.0069 & -0.0003 & 0.00001 & -0.0011 & 0.0017 & -0.0005 \\
\hline GFP & 0.0002 & 0.0001 & -0.0003 & & -0.0010 & 0.0001 & 0.00001 & 0.0001 & 0.0001 & -0.0002 \\
\hline GFR & -0.0018 & 0.0000 & 0.0000 & -0.0001 & & 0.00001 & 0.00001 & 0.0002 & -0.0003 & 0.0002 \\
\hline $\mathrm{PH}$ & 0.0001 & -0.0002 & -0.0011 & -0.0087 & -0.0570 & & 0.0002 & 0.0092 & -0.0157 & 0.0072 \\
\hline No. $S / m^{2}$ & -0.0003 & 0.0005 & 0.0017 & 0.0165 & 0.1393 & 0.0001 & & -0.0157 & 0.0417 & -0.0267 \\
\hline No. G/S & -0.0087 & 0.0013 & 0.0018 & 0.0306 & 0.0502 & 0.0002 & -0.0001 & & 0.0165 & -0.0097 \\
\hline sw & 0.1393 & 0.0008 & 0.0069 & 0.0502 & 0.8596 & -0.0010 & $\mid-0.0018$ & -0.0570 & & -0.0882 \\
\hline $1000-\mathrm{Kw}$ & 0.0202 & -0.0004 & -0.0005 & -0.0097 & -0.0882 & -0.0002 & 0.0002 & 0.0072 & -0.0267 & \\
\hline
\end{tabular}


According to the indirect path coefficient analysis; seven positive indirect path coefficient found as follows: grain filling rate had the highest indirect effect an appreciable indirect effect via a spike weight with value 0.8596 followed by the relationship between grain filling rate via no. spike $/ \mathrm{m}^{2}$ with value 0.1393 , grain filling rate via no. spike $/ \mathrm{m}^{2}$ with value 0.0502 , grain filling period via spike weight with indirect value 0.0502 , spike weight via no. spikes $/ \mathrm{m}^{2}$ with indirect value 0.0417 , grain filling period via no. spikes $/ \mathrm{m}^{2}$ with a positive indirect value 0.0306 and grain filling period via no. spikes $/ \mathrm{m}^{2}$ with a positive indirect value 0.0165 . On contrary, two negative indirect path coefficient appear among 1000-kernel weight via spike weight with indirect value -0.0882 and 1000 -kernel weight via no. spikes $/ \mathrm{m}^{2}$ with indirect value $\mathbf{- 0 . 0 2 6 7}$. From path coefficient analysis, can be summarized that more emphasis may be given on grain filling rate and grain filling period along with spike weight, no. spikes $/ \mathrm{m}^{2}$ and no. of grains/spike could be useful selection criteria in wheat breeding.( Solomon and Hanchinal, 2013 and EI-Shal, 2016) they found that, path coefficient not only measures the direct influence of one variable upon another, but provides means of partitioning both direct and indirect effects and effectively measuring the relative importance of causal factors which helps to build an effective selection program.

\section{Stepwise regression:}

The analysis of stepwise regression was conducted by taking into account the grain yield as the dependent variable and the rest of properties as independent variables in Triticum aestivum genotype. Stepwise regression is a semi-automated process of building a model by successively adding or removing variables based solely on the t-statistics of their estimated coefficients. In order to remove effect of non-effective characteristics in regression model on grain yield, stepwise regression was used.

The results of stepwise regression are showed in Table (7). Stepwise regression is grain yield /plot used as dependent variable and other traits used as independent. The grain filling period (GFP), grain filling rate (GFR) and plant height $(\mathrm{PH})$ with $\mathrm{R}^{2}=99.81 \%$, had justified the maximum of grain yield $\mathrm{m}^{-2}$ changes. The other characters were excluded from the model for their low relative contributions. It is observed from the results in Table (7). Grain filling rate was the most important character followed by grain filling period and plant height. Based on the final step of stepwise regression analyses, the equation for prediction of grain yield $\mathrm{m}^{-2}$ will be:

Grain yield $=-2.446+0.06$ grain filling period +46.81 grain filling rate- 0.003 plant height.

Table 7: Regression coefficient (b), standard error (SE), t-value, and probability $(P)$ in predicting wheat grain yield plant by the stepwise procedure analysis

\begin{tabular}{|c|c|c|c|c|c|c|}
\hline Step & Variable entered & $b$ & SE & t-Value & $P$ & VIF \\
\hline 1 & Grain filling period & 0.06 & 0.003 & 19.73 & 0.00 & 1.12 \\
\hline 2 & Grain filling rate & 46.81 & 0.51 & 91.65 & 0.00 & 1.12 \\
\hline 3 & Plant height & -0.003 & 0.002 & -1.55 & 0.14 & 1.02 \\
\hline
\end{tabular}

Constant $=-2.446, R^{2}=99.81, R^{2}($ adjusted $)=99.78$ 
Existence of significant $\mathrm{R}$ square in a successful regression equation indicates the effectiveness of these traits to increase grain yield (Leilah and AlKhateeb, 2005). These results are similar to reported by Fouad, (2018).

\section{Conclusion}

According to the traits in the study results revealed the existence of considerable variations among wheat genotypes that can be utilized in effective selection for breeding program. Insignificant interaction mean squares between genotypes and year were detected for all studied traits except for days to maturity, spike weight, grain filling rate and grain yield Iplot. Heritability estimates of the studied traits were found high in most characters except three of them; plant height, no. spikes $/ \mathrm{m}^{2}$ and no. grains/ spike which recorded the lowest heritability values. Therefore, high heritability values with low variation due to genotypes $x$ year interaction in the most of the important traits implies that traits are inherited quantitatively. In this study, days to maturity, grain yield /plot, grain filling rate and days to heading showed high heritability, significant positive genotypic correlation. These traits are, therefore, the key contributors to grain yield and should be focused on crop improvement wheat breeding program for increasing grain yield. As well as path coefficient analysis, should be given on grain filling rate and grain filling period along with spike weight, no. spikes $/ \mathrm{m}^{2}$ and no. of grains/spike could be useful selection criteria for wheat breeding.

\section{REFERENCES}

Abd El-Kreem, Thanaa H. A. and Hayam S. A. Fateh (2016). Assessment of genetic variability, diversity and association in fifteen bread wheat genotypes. Alex. J. Agric. Sc. 61, (3); 333-344.

Ali, Y., B. M. Atta, J. Akhter, P. Monneveux and Z. Lateef (2008). Genetic variability association and diversity studies in wheat (Triticum aestivum L.) germplasm. Pak. J. Bot., 40(5): 2087-2097.

Allard, R.W. (1960). Principles of Plant Breeding. John Wiley and Sons, New York, USA, $46 \mathrm{p}$.

Arya, V. K., J. Singh, L. Kumar, R. Kumar, P. Kumar and P. Chand (2017). Genetic variability and diversity analysis for yield and its components in wheat (Triticum aestivum L.). Indi. J. Agric. Res., 51(2), 128-134.

Baloch, M. J., E. Baloch, W. A. Jatoi and N. F. Veesar (2013). Correlations and heritability estimates of yield and yield attributing traits in wheat (Triticum aestivum L.). Pak, J. Agri., Eng., Vet. Sci. 29 (2): 96-105

Baye, A., B. Baye, B. Muluken and D. Bitwoded (2020). Genotypic and phenotypic correlations and path coefficient analysis for yield and yieldrelated traits in advanced bread wheat (Triticum aestivum L.) lines. Cogent Food \& Agric., 6; 1-17.

Dargicho, D., A. Sentayehu, E. Firdisa and A. Ermias (2015). Path coefficient and correlation studies of yield and yield associated traits in bread wheat (Triticum aestivum L.) germplasm. World Appl. Sci. J., 33 (11): 1732-1739.

Demelash, A.L., D. Tadesse and A. Getachew (2013). Genetic variation of bread wheat (Triticum aestivum L.) genotypes based on number of phonological and morphological traits at Marwold Kebele, Womberma Woreda, West Gojam. Wudpecker J. Agric. Res. 2(6); 160 - 166.

Draper, N. R. and H. Smith (1981). Applied regression analysis. 2nd edition. Wiley series in probability and mathematical 
statistics. John Wiley \& Sons. N.Y., pp. 709.

Dryden, I.L. and K.V. Mardia (1998). Statistical shape analysis. Wiley, London, 5p.

El-Shal, M. H. (2016). Correlation and path coefficient analyses in durum wheat genotypes. Egypt. J. Plant Breed. 20 (4):1 -11.

Fikre, G., S. Alamerew and Z. Tadesse (2015). Genetic variability studies in bread wheat (Triticum aestivum L.) genotypes at kulumsa agricultural research center, South east Ethiopia. J. of Biology, Agric. and Healthcare, 5(7), 89-98.

Fouad, H.M. (2018). Correlation, path and regression analysis in some bread wheat (Triticum aestivum L) genotypes under normal irrigation and drought conditions. Egypt. J. Agron.40, (2): 133 - 144.

Grafius, J.E. (1960). Does over dominance exist for yield in corn. Agronomy Journal (52): 361-365.

Hussain, T., T. A. Muammad, A. Zahid, I. Javed, R. Attiq and R. Ghulam (2014). Estimation of some genetic parameters and inter-relationship of grain yield and yield related attributes in certain exotic lines of wheat (Triticum aestivum L.) J. of Bio., Agriculture and Healthcare, 4 (2): 4853.

Ismail, A.A. (2001). Identification of selection traits for yield improvement of bread wheat using path analysis. Assiut J. Agric. Sci., 32(2): 63-84.

Johnson, H.W., H.E. Robinson and R.E. Comstock (1955). Estimates of genetic and environmental variability in soy bean. Agron. J., 47: 314-318.

Khokhar, M.I., M. Hussain, M. Zulkiffal, N. Ahmad and W. Sabar (2010). Correlation and path analysis for yield and yield contributing characters in wheat (Triticum aestivum L.) Afr. J. Plant Sci., 4(11): 464-466.

Kwon, S.H. and J.H. Torrie (1964). Heritability and relationship among traits of two soybean populations. Crop Sci., 4: 196-198.

Leilah, A.A and S.A. Al-Khateeb (2005). Statistical analysis of wheat yield under drought conditions. J. Arid Environ. 61:483-496.

Mecha, B., A. Sentayehu, A. Alemayehu, A. Ermias and D. Dargicho (2017). Correlation and path coefficient studies of yield and yield associated traits in bread wheat (Triticum aestivum L.) genotypes. Adv Plants Agric Res.; 6(5):128-136.

Minitab, (2020). Minitab Reference Manual, Release 19 for Windows. PA: Minitab Inc. State College, Harrisburg, Pennsylvania, USA.

Mohammadi, M., P. Sharifi, R. Karimizadeh, M. Kazem and M.K. Shefazadeh (2012). Relationships between grain yield and yield components in bread wheat under different water availability (dry land and supplemental irrigation conditions). Not. Bot. Hortic. Agrobo. 40(1): 195-200.

Nukasani, V., R. P. Nilkanth, B. Swati, D. Shradha and S. M. Sachin (2013). Genetic variability, correlation and path analysis in wheat. J. Wheat Res. 5 (2): 48-51

Reeve, E. (1955). The variance of genetic correlation coefficient. Biometrics, 11: 357-374.

Robertson, A. (1959).The sampling variance of genetic correlation coefficient. Biometrics, 15: 469-485

Roy, D. (2000). Plant breeding: Analysis and exploitation of variation. Norsa Publishing House, New Delhi, 728 p.

Saleem, U., K. Ihsan, M. Tariq and R. Muhammad (2006). Phenotypic and genotypic correlation coefficients 
between yield and yield components in wheat. J. Agric. Res., 44(1): 1-7.

Singh, R.K. and B.D. Chaudhary (1985). Biometrical methods in quantitative genetic analysis. Kalyani publishers, Ludhiana, New Delhi, 54-57.

Singh, S.P. and V.K. Diwivedi (2002). Character association and path analysis in wheat (Triticum aestivum L.). Agric. Sci. Digest, 22(4): 255-257.

Solomon, G. and R. R. Hanchinal (2013). Correlation and path analysis in yield and yield components in spring bread wheat (Triticum aestivum L.) genotypes under irrigated condition in Southern India. Afric. J. Agric., Res. 8(24): 3186-3192.

Steel, R.G.D, J.H. Torrie and D. A. Dickey (1997). Principles and Procedures of Statistics: A Biometrical Approach. $3^{\text {rd }}$ ed. McGraw Hill Book Co. New York.

Zafarnaderi, N., S. Aharizad and S.A. Mohammadi (2013). Relationship between grain yield and related agronomic traits in bread wheat recombinant inbred lines under water deficit condition. Ann. Biol. Res. 4(4): 7-11. 
تقدير معامل الارتباط ومعامل المرور ومعامل الانحدار لبعض الصفات الكمية في قمح الخبز

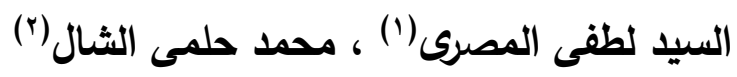

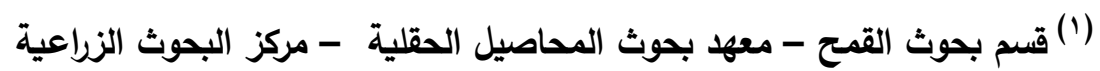

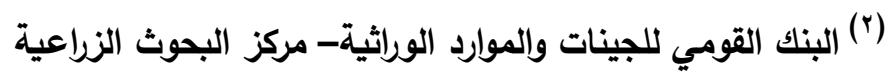

الملخص العربي

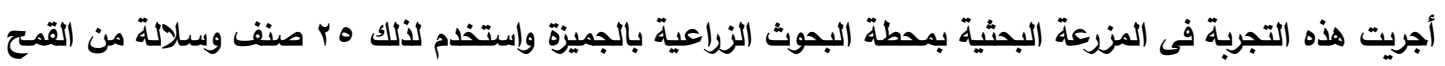

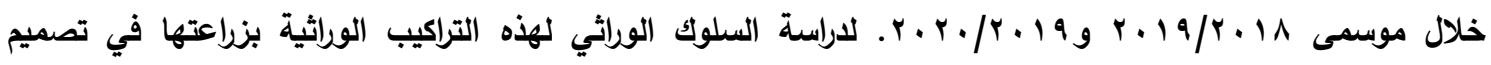
القطاعات الكاملة العشوائية في ثلاث مكررات لتقدير التصنيفات الوراثية والمظهرية وذلك باته باستخدام مكونات التباين

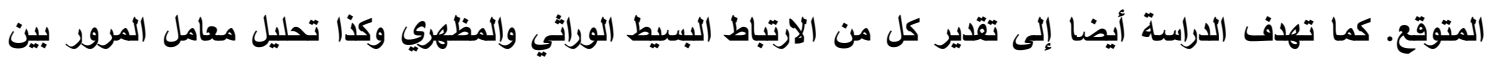

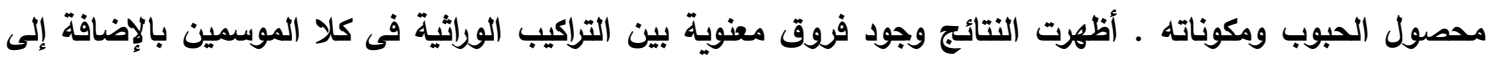

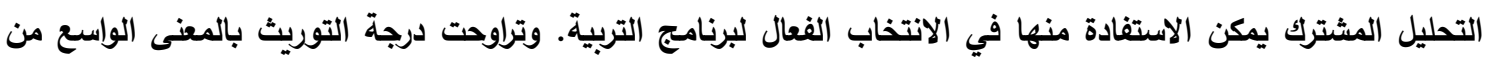

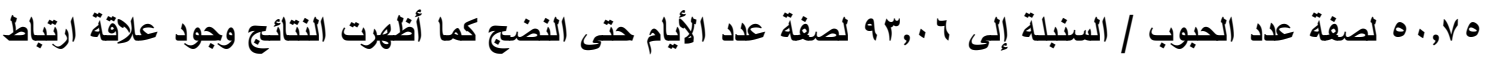

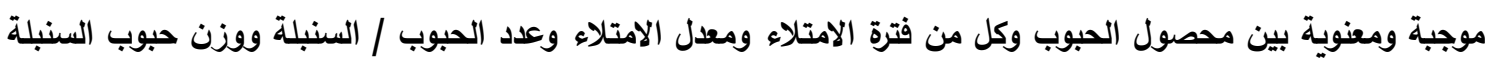

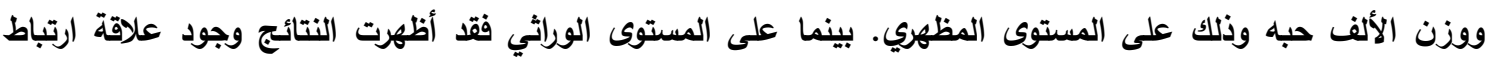

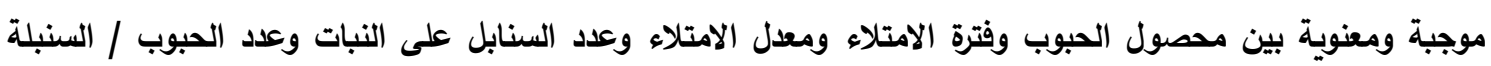

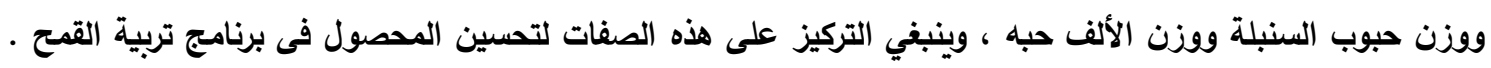

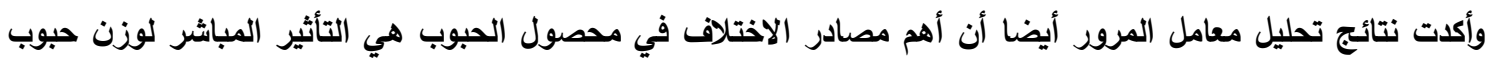

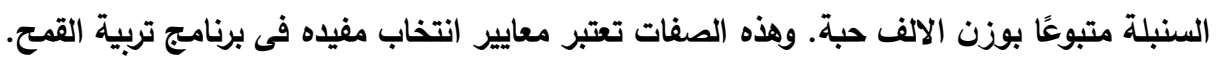

السادة المحكمين

أ. أد/ محروس عبدالغنى أبوشريف مركز البحوث الزراعية

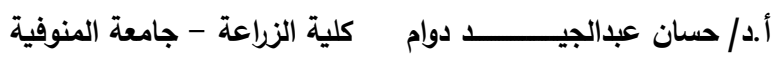

